\title{
食道静脈瘤の内視鏡的検討
}

*遠藤 光夫, 小林誠一郎, 木下 祐宏
山田 明義, 鈴木 茂, 井手 博子
萩野 知已, 林 恒男, 吉田 操

\section{Clinical Studies of Esophageal Varices}

Mitsuo Endo, M.D., Seiichiro Kobayashi, M.D., Yuko Kinoshita, M.D., Akiyoshi Yamada, M.D.,

Shigeru Suzuki, M.D., Hiroko Ide, M.D., Tomomi Ogino, M.D., Tsuneo Hayashi, M.D., and Misao Yoshida, M.D.

Institute of Gastroenterology, Tokyo Women's Medical College, Tokyo

Sixty-two cases of esophageal varices have been examined in our hospital for the last one and a half years. Bleeding varices were found in 32 cases. The characteristic differences in the esophagoscopic findings between bleeding and non-bleeding varices were as follows. (1) Varices extending the entire length of the esophagus were seen in the bleeding cases more often. (2) Bluish varices were seen in $25 \%$ of the bleeding cases, while they were found in $8 \%$ of the non-bleeding cases. The red sign was found in the majority of the bleeding cases. (3) The tumorous and nodular forms of varices were found in the bleeding cases more frequently. (4) Erosive esophagitis was rare, and it was seen in only 2 of the bleeding cases.

Forward viewing fiberscopes, such as the esophagofiberscope and the pan-endoscope, were utilized for the examination of the varices. An esophagofiberscope with a tip bendable up to 210 degrees was especially appropriate for observation throughout the esophagus and the gastric cardia.

In 334 cases of urgent endoscopy, gastric or duodenal ulcers were found in $51 \%$. Esophageal varices were seen in $11 \%$, in some of which gastric and/or duodenal lesions were also found.

For the surgical treatment of esophageal varices, esophageal transection, splenectomy and devascularization around the stomach have been carried out. Transection of the esophagus was easily performed using a sewing instrument. In a long-term follow-up over one year after surgery, a relapse of varices was seen in $10 \%$ of the cases.

食道静脈瘤の診断に打ける内視鏡検査の意義は大き く, 従来よりいろいろと報告されてきたが22-5), 診断 面の検查に, flexible のファィバースコープが用いら れるようになって，やっと静脈瘤を禁忌とすることも なくなった。しかし，その診断基準については，まだ 統一的なものがなく，各自の診断基準で討論されてき たのが現状である。

*東京女子医科大学消化器病センタ一外科
最近になり，門脈王穴進症研究会（門立症研究会） より，一つの試案が示され1)，できるだけ同じ基盤に たっての集計がょびかけられているので，今回は，こ の診断基準に基づいて検討を加えてみた。

1. 門充症研究会による食道静脈瘤のの内視鏡診断基 準 (表 1 )

a . 占居部位

この基準では, 内視鏡所見を, 部位, 色調, 形態, 
表 1 食道静脈瘤の内視鏡診断基準(門光症研究会)

\begin{tabular}{|c|c|c|}
\hline 内視鏡所見 & 記号 & 細 \\
\hline $\begin{array}{l}\text { 食道静脈瘤 } \\
\text { の占居部位 }\end{array}$ & $\mathrm{L}$ & $\begin{array}{l}\mathrm{Lg} \text { : 胃静脈瘤 } \\
\mathrm{L} 1 \text { : 食道静脈瘤 } \text { 下部食道 } 1 / 3 \\
\mathrm{Lm}: \text { 食道静脈瘤 } \text { 中部食道 } 1 / 3 \\
\mathrm{Lu}: \text { 食道静脈瘤 } \text { 上部食道 } 1 / 3\end{array}$ \\
\hline $\begin{array}{l}\text { 食道静脈瘤 } \\
\text { の色調 }\end{array}$ & $\mathrm{C}$ & $\begin{array}{l}\mathrm{Cw}: \text { 白色調の静脈瘤 } \\
\mathrm{C}_{\mathrm{B}} \text { : 青色調の静脈瘤 } \\
\mathrm{Cr} \text { : 発赤 } \\
\text { [註]登赤々ついてはびをん性 } \\
\text { 発, 樹枝状血管像, 血 } \\
\text { 腫状発赤などと付記する }\end{array}$ \\
\hline $\begin{array}{l}\text { 食道静脈瘤 } \\
\text { の形態 }\end{array}$ & $\mathrm{F}$ & 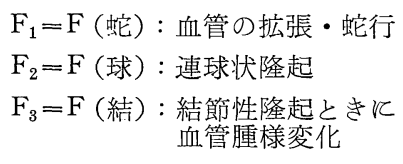 \\
\hline 随伴食道炎 & $\mathrm{E}$ & $\begin{array}{l}\mathrm{E}_{0}: \text { Erosion を伴わない } \\
\mathrm{E} \text { : Erosion を伴う }\end{array}$ \\
\hline
\end{tabular}

随伴食道炎の 4 つの因子に分けて検討する。

部位については，食道を 3 分し，上部 $1 / 3$ を $\mathrm{Lu}$, 中 部 $1 / 3$ を $\mathrm{Lm}$, 下部 $1 / 3$ をl とし, 胃静脈瘤を $\mathrm{Lg}$ とし，内視鏡所見では，気管分岐部までを Luとし て，それから食道胃接合部をでを 2 分し， Lm, Ll と するとしている。しかし，実際に内視鏡所見では，左 気管支による圧迫は識別できても，分岐部を知ること はむずかしく，例え壮逆流性食道炎でみても，この压 迫部の上部と下部で異なった所見を示すとともあっ て, 左気管支の圧迫部と大動脈弓によると思われる圧 迫，この附近を第 2 狭窄部と考えこれより上部を $\mathrm{Lu}$ とし，この肚門側，食道胃接合部までを距離の上から 2 分するということになる。

\section{b. 色調}

色調については白色静脈瘤と青色静脈瘤とに分け， 赤色調は $\mathrm{Cr}(+)$ とし，その形態ととも飞付記するよう 飞する。色調で，白色か青色かということは，視診時 の色調で判断するようにするので，八ロゲン電球とク セノン電球とで多少の色調のちがいもあるが，何より む，視診時の色調を，写真で忠実婊現できるように することが大切である。われわれは，クセノン光源で の食道の内視鏡写真がやや褐色調を扣びることから， 色变換フィルターとして, コダックラッテンフィルタ 一 CC 50 Cと CC $20 \mathrm{M}$ を 2 枚重㸚合わせ，これをカメ ラのアタッチントにはりつけて写真撮影をして, 視診 時の色調を再現するようとしている。静脈瘤の多くが
$\mathrm{CW}$ で， $\mathrm{CB}$ 即青色静脈瘤はかなり少ない。

発赤 $(\mathrm{Cr})$ は, 白色静脈瘤, 青色静脈瘤の上飞みられ るものを陽性と考光, その形から, 血腫様, 樹枝状, つる状など，形状を考えて記載するわけである。 c. 形態

静脈瘤の形態は, $\mathrm{F}_{1}$ 拡張, 蛇行するもの, $\mathrm{F}_{2}$ 連珠 状になるもの, $\mathrm{F}_{3}$ 結節性隆起, 血管腫様変化を示す もの，と飞分けている。静脈瘤の程度は，普通下部食 道ほど高度になるもので, 1 人の例でも, $\mathrm{Lu}$ 飞 $\mathrm{F}_{1}$ が あり, Ll 飞 $\mathrm{F}_{2 \sim 3}$ というあのが多くをしめている。

\section{d. 随伴食道炎}

随伴食道炎としては, 明らかに陷凹をみる発赤や白 苔を括びた陷凹など，まず，はっきりと“びらん”と 読めるもののみを，食道炎とすることにした方がよ い。発赤とよめるものも，近接拡大すると，細血管の 集簇したあのであるとわかるあのがかなり多い。食道 炎は, 食道裂孔ヘルニアに伴う静脈瘤の症例に多くみ られる。

\section{2. 使用内視鏡器種}

食道静脈瘤は, 多くの場合食道だけでなく胃, とく に噴門部にもみられ，出血例の内視鏡検査でも，食道 ではなく、はっきり胃内からの出血, それも噴門部の 静脈瘤からとされたものが時々ある。また，静脈瘤に は，胃潰瘍など胃病変の合併をみることもあって，食 道から胃まで，とくに噴門部を十分飞観察できる器種 が適当で, 現在は前方視の内視鏡として, 食道ファ1 バースコープや, Panendoscope (とくに GIF-P 2 ), が用いられている。以前には, 一度食道ファィバース コープで食道内を観察, 再び胃ファィバースコープに かえて, 胃内の観察を, ということああったが, 現在 は一本の内視鏡で食道から胃まで観察してしまってい る。それは，食道ファィバースコープでも，十分に噴 門部を観察しうるように器械を改良したためで, 現在 われわれは, 静脈瘤に対して食道ファィバースコープ と Panendoscope とを全く同じそ使用している。

図 1 は, ルーチンとしている食道ファィバースコー プで, 上段は通常径で, 先端部を 210 度と強くアング ルのかかるようにした強アングル $\mathrm{EF}-\mathrm{B}_{2}$, 中段は径 $7 \mathrm{~mm}$ の EF-PA, 下段は径 $9 \mathrm{~mm}$ の EF-P 2 (short GIF $\left.-\mathrm{P}_{2}\right)$ である。強アングル $\mathrm{EF}-\mathrm{B}_{2}$ は一杯林ン゙ルを かけると，スコープの軸の屈曲部から $5 \mathrm{~cm}$ のところ から視野に入ってきて, 噴門部で, 食道胃接合部領域 から, 噴閣唇の穹隆部側, 穹隆部, さらに胃上部と, 胃の上部に全く観察盲点と生検できないところがなく 本当の意味の食道鏡とすることができた。四 2 は，胃 


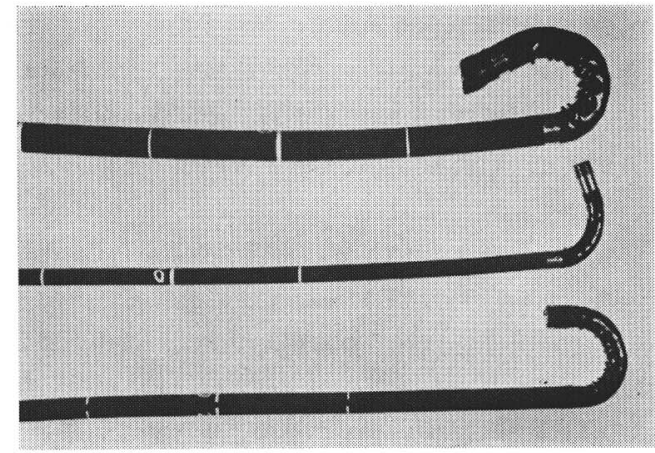

図 1 食道ファィバースコープ

上段：強アングル $\mathrm{EF}-\mathrm{B}_{2}$ 中段 : EF-PA (径 $7 \mathrm{~mm}$ )

下段 : EF-P 2 (径 $9 \mathrm{~mm}$ )

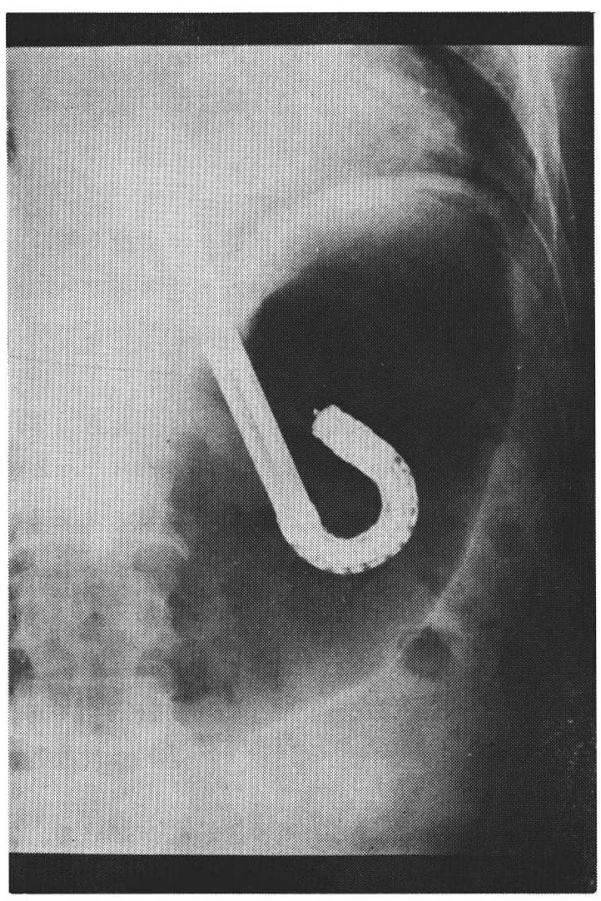

図 $2210^{\circ}$ アングルルよる噴門部の観察

噴門部で接合部領域を逆視観祭しているもので, 逆視 も器械自身の機構でできるため, 胃の大弯側の壁に負 担をかけず，患者の反射も少ない。しかも，噴門を正 面視として観察できるのも特徴である。

食道静脈瘤の内視鏡検査では, ともかく食道の内腔 を, 視野の中心に括くようにしてすすめていけげ, 全 周性に腫瘤状に内腔を閉鎖しているようにみえる静脈 瘤でも, 安全に食道の奥まで插入できる。しかし, 送 気により食道内腔を拡げる際に, 急激に送気をする
と，粘膜のごく表面から，出血をみることがある。

胃静脈瘤飞ついては, じゅず状, 腫瘤状などど, 形 態も様々で, 程度も様々であるが, とく飞胃静脈瘤が 大きく, はじめにX線検査で胃粘膜下腫瘤として発見 されることがある。この際, 内視鏡所見で, 食道飞静脈 瘤としての所見がみられなくても, 粘膜が青藍色を呈 し, 粘膜の細血管の拡張や増生がみられる, などの特 徴的な所見をみるので，これが胃の静脈瘤との釷断面 で間接的に役に立つものである。

3. 静脈瘤出血と内視鏡像との検討

門六症研究会基準に基づいての記載例62例につき, 出血と各因子との関係についてみた。出血例は 32 例, 非出血例は30例である。

先ず部位との関係では, 出血例では, Lu, Lm, L1 の頻度がほぶ同じ，つまり，Lu〜Ll とほぶ全長にわ たりみられる例が多いということになる。これに対し て, 非出血例では, $\mathrm{Lm}, \mathrm{Ll}$ と, 中部以下にみられた ものの多いことを示している。出血例では, 胃静脈瘤 の頻度も $91 \%$ と高いが，非出血例では，50\%であった (表 2 )。

表 2 部位別検討

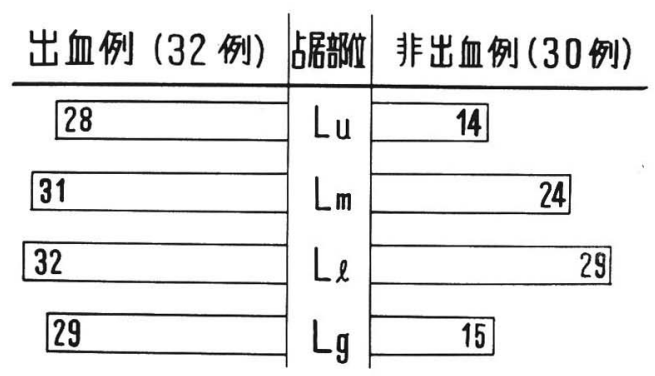

次に色調との関係では, 出血例, 非出血例とも白色 静脈瘤 $(\mathrm{CW})$ が多くなっている。しかし, 出血例で青 色静脈瘤 (CB) が $25 \%$ と, 非出血例の $7 \%$ と比べ頻度 が高くなっている。

発赤 (Cr) の因子では，出血例には $88 \%$ と大部分が $\mathrm{Cr}(+)$ であった。非出血例でも56\%にみられた。発赤の 形態（例えば血腫状，樹枝状など）には，余り差がな く, 混合してみられるものが多い。な招，青色静脈瘤 には，全例， Cr sign が陽性であった（表 3 )。

形態との関係では，一番 $\mathrm{F}$ の番号の高いものを巽ん で検討してみたが，出血例では $\mathrm{F}_{3}$ と腫瘤状に大きい むのが56\%と多く, 非出血例での $23 \%$ 差をみること ができる。反面, 非出血例では, 蛇行・拡張位の $\mathrm{F}_{1}$ 
表 3 色調による検討

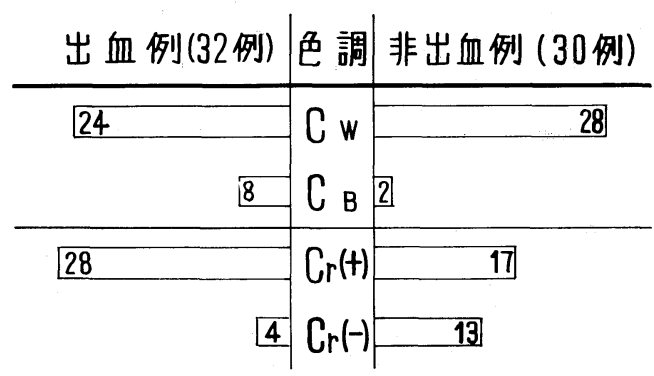

表 4 形態別検討

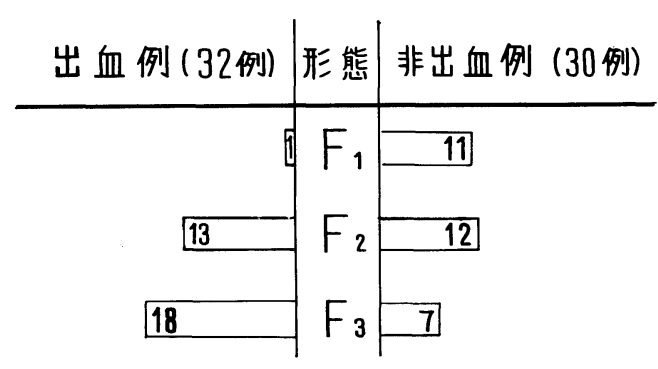

表 5 食道炎合併の有無

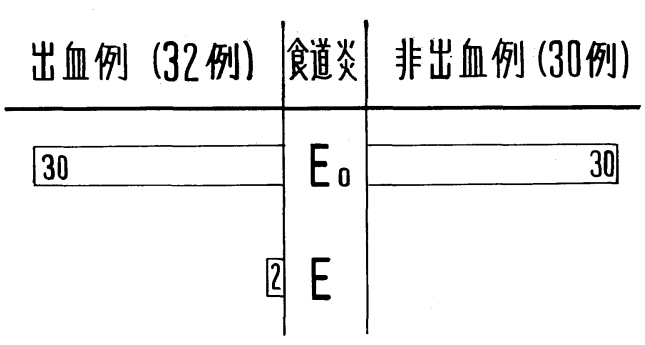

の頻度がふえている（表 4 ）。

随伴食道炎は，もともと少ないものであるが，出血 例飞 2 例 $(6 \%)$ みられたが，非出血例にはみられな かった（表 5 ）。この食道炎は，いずれも食道裂孔へ ルニア合併例で，食道胃接合部上の食道側にみられ， 1 例は周辺飞細血管の放射状の増生をみる登赤, 陷凹， 1 例は陷凹面飞白苔の附着をみたものである。

以上, 各因子別飞出血例, 非出血例をみてみたが, 出血例では, 部位では上部から全長にわたってみられ， 形態的には連珠状から腫瘤状となる。Gradeでいうと
中等度から高度のものとなる。色調では，青色静脈瘤 (C B ) は, $\mathrm{Cr}(+)$ (発赤) む必ず伴い, やはり出血飞 対しては, 最も要注意ということになる。白色静脈瘤 でも, $\mathrm{Cr}(+)$ に出血例が多いので, 形態が $\mathrm{F}_{3}$ (腫瘤, 結節状）で，ほぼ全長，全周性にみられるものでは， $\mathrm{Cr}(+)$ 例も多く出血飞対して十分注意が必要である。

\section{4. 緊急内視鏡検査}

出血後48時間以内飞施行した上部消化管出血例の緊 急内視鏡検查は，334 例である。その疾患別では，胃 潰瘍, 十二指腸潰瘍が压倒的飞多くなっているが, 静 眽瘤はこれにつぎ38例，11\%である。静脈瘤は，食道 関係の出血例では，58\%と半数以上をしめる(表 6 )。

表 6 上部消化管出血飞対する緊急内視鏡検查 (1972 1978. 6)

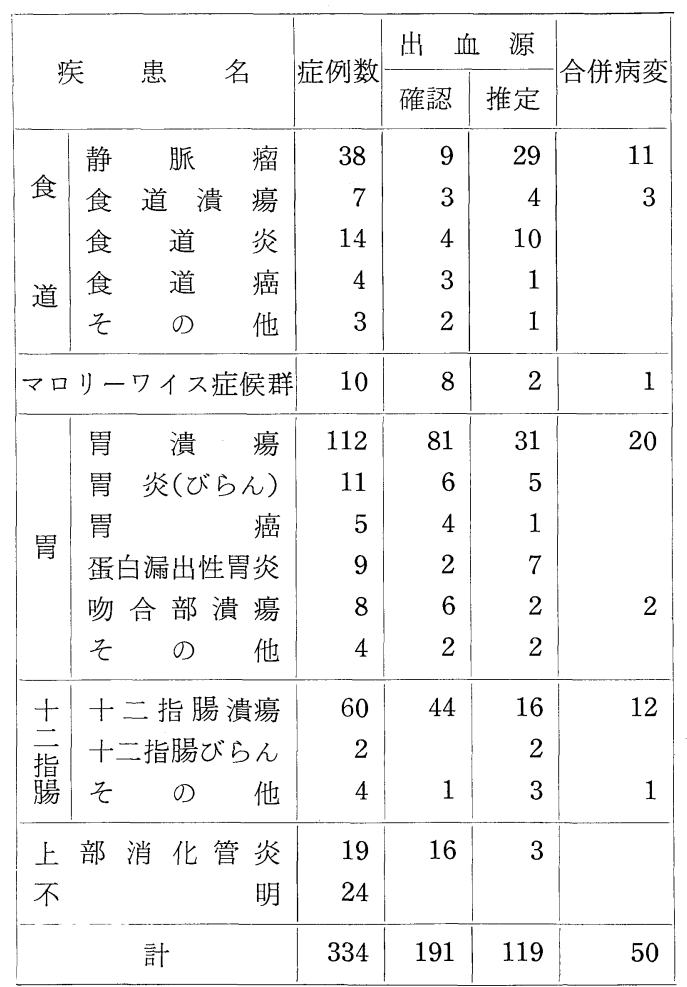

胃潰瘍や十二指腸潰瘍では止血していても，凝血が 附着していたりで，出血源を確認できるものが多いの 飞比べ, 静脈瘤では, 検査時出血源が分からず, 推定 と診断されるものが多くなっている。猶, 静脈瘤で は, 合併病変として胃病変の合併が多くなっているの も特徵的である。

緊急内視鏡検查で, 潰瘍性病変の他, 逆流性食道 
炎，マロリーワイス症候群，食道下端から胃前庭部， 十二指腸球部まで, 広くびらん性变化をみるいわゆる 上部消化管炎，などがあるが，これらは，内視鏡検査 にて確診のつき易いものである。逆流性食道炎でも, 急飞疼痛（器下痛, 胸骨後部痛, 心窩部痛）とともに 吐血をみるいわゆる急性食道炎に入るものは，食道に 広くびらん性変化をみる。これは, 経過が早く, 内科 的治療で 1 週間位で症状は殆んど消失, 内視鏡像も 2 〜3 週で全く痕跡をみない位になる。しかし，上部消 化管炎とは発症が異なる。これは多くの場合，鎮痛消 炎剤の服用後にみられるなど，他の因子が関与してい るととが多い。マロリーワイス症候群も, 内視鏡㭘査 では容易に診断ができるが，下部食道噴門部というこ とと, この病変が浅いということとで, X線診断はか なりむずかしい。

さて, 出血中の静脈瘤飞対する緊急内視鏡検査であ るが，前述の他疾患との鑑別に，それはX線検査でわ かりにくいものも多いということと, また, 静脈瘤か らの出血としても, 食道からか, 胃内からかというこ とで, 緊急処置の方法も異なるということもあって, 予め, 静脈瘤と診断のついている場合も, 積極的に内 視鏡検査を行なうょうにしている。

静脈瘤出血の場合, 本当に出血している部位を確認 できることは少なく，出血が多いとされる下部食道で は, 食道内腔全体飞新鮮血が充満し, 水洗し, 吸引し て, 一時, 粘膜面がみえても, 次の瞬間にまた大量に 血液が眼前にあふれ出るという感じの所見をうける。 しかし, 中部以上の食道では, 食道内腔が開いている ことああって,水を入れた風船に針で穴をあけて, 線状 に水がほとばしるようと，ふき出した血線を認められ るものもある。このような場合は，処置も適切に行な い得る。図 3 では, 切歯より $27 \mathrm{~cm}$ の後壁の静脈瘤か ら，左前壁に血線が噴射しているのを診断できた。 Sengstaken-Blakemore チューブを插入，1日で止血 しえた例である。

出血が食道からか胃からかの診断は容易である。胃 からの出血であると, 食道内を水洗し, 吸引しつつス コープをすすめると，血液がなくなり，食道の粘膜や 静脈瘤の表面をみれるようになる。しかし, 食道下端 から一寸でも胃内に挿入した途端, 視野が血液で真赤 そなってしまう。胃からの出血例でも, 潰瘍では, 一 寸でも時間がたったものでは, 潰瘍を識別でき, 出血 の模様なども観察できることが多い。

5. 内視鏡による術後の経過

静脈瘤の外科治療として, われわれは開腹し, 器械
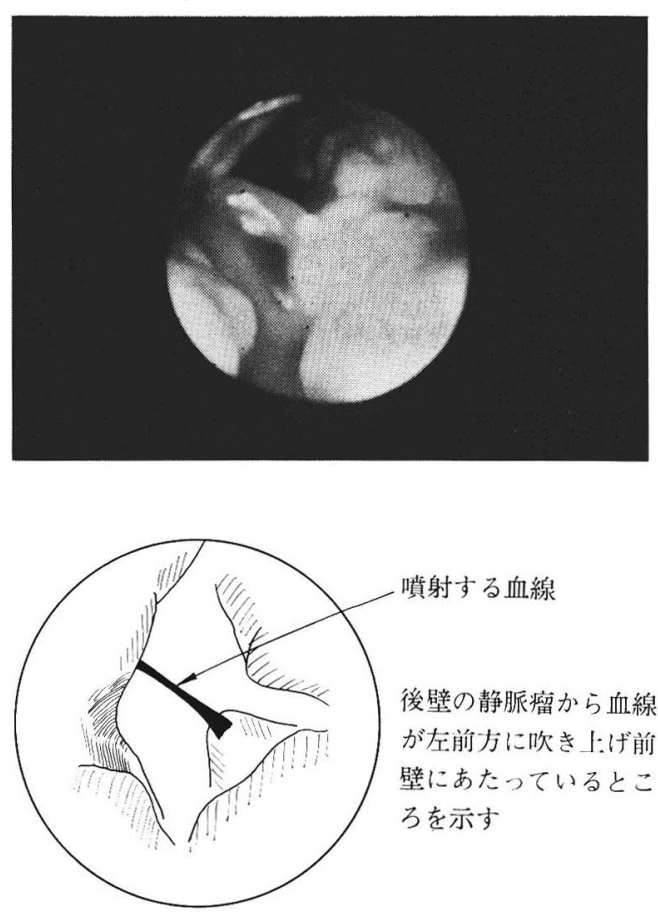

図 3

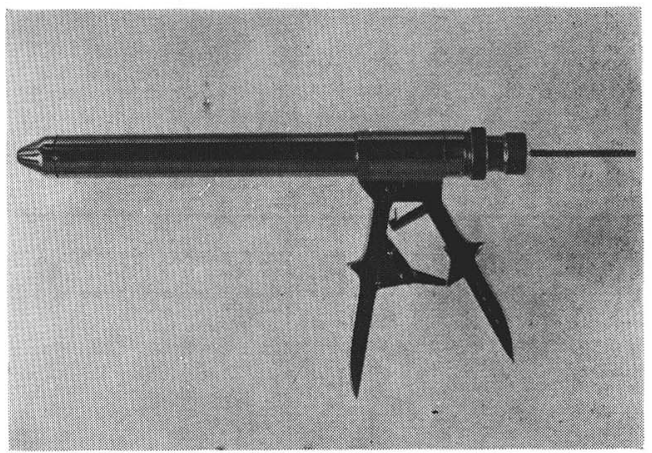

図 4 ソ連製腸管吻合器 (ЛКС-25M)

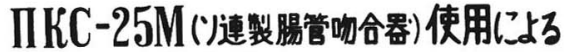 食道離断シェーフ}

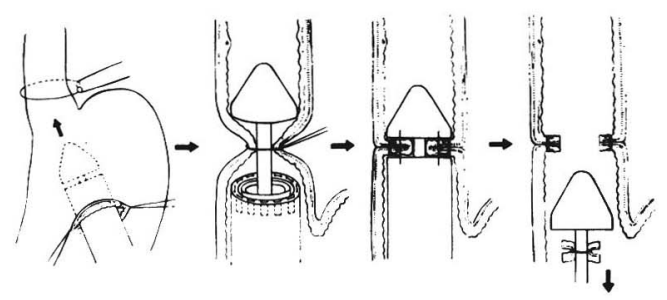

図 5 
による食道離断術を施行している。摘脾, 胃周囲血管 の結紮と腹部食道の離断を行なうが, 器械として, ソ 連製腸管吻合器 ЛKC-25M の改良型を使用している (図 4 )。胃飞小切開を加觉, 器械を食道内飞装着, 八 ンドルの操作で, 一気に食道の離断と一層の内㼑縫合 が行なえる訳で, 出血量も少なく, 短時間で離断縫合 の行なえるのが利点である（図 5 )。

食道離断術施行例古内視鏡的飞経過追求し，5 个月 以上追求例について, 静脈瘤の消長をみてみた。手術 の対象は中等度, 高度と Grade の高いものである。 手術効果の内視鏡所見として, 静脈の蛇行拡張を認め ないものは有効とし, たとえ, 静脈の拡張, 蛇行を恐 めても, 送気により容易に平低化されるもの, 固く血 栓化を思わせるすの, などは非活動性の静脈瘤として 効果があったと判定した。この基準からみると， 1 例 飞無効をみる他は，すべて有効例であった。

長期の経過をみるに, 殆どが 1 〜 ケ旦での検査所 見を維持したが， 1 例に，1年までは効果をみて，殆 んど消失していた静脈瘤が, 2 年目で, 蛇行, 拡張, 一部飞連珠状の所見をでみえるょうに増悪がみられた (忷6)。

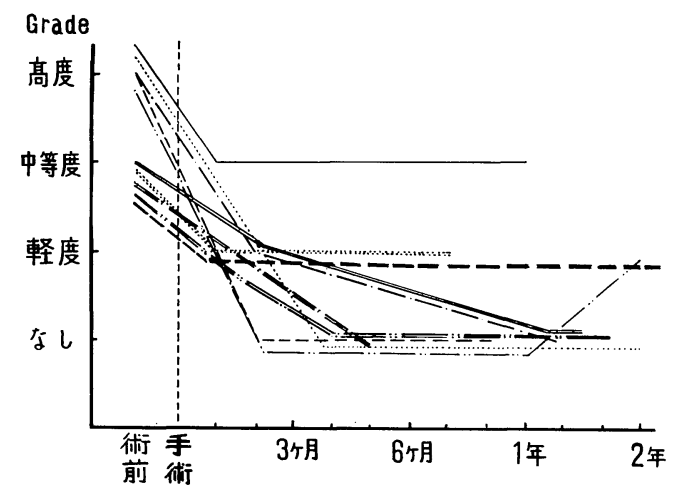

図 6 食道離断術後の経過

\section{ま と め}

食道静脈瘤の内視鏡検査について, 門穴症研究会で の診断基準につきまとめてみた。この診断基準当; 言 葉と実際の所見との間汇，各施設でかなりの差がある ことが予想される。とくに色調で, 白色静脈瘤か青色 静脈瘤かということでは, 視診の状態で論じるべく, 写真上, 視診時の色調に再現すべく若干の細工を必要 とした。また, 食道炎の発赤についても, 近接観察し, びらんと血管集族像との鑑別をつけている。

出血例の所見では, 食道の全長にわたってみられる あのに, 形態では, 腫瘤状のものに, 発赤 (Cr) は陽 性例に, 出血例が多くみられた。

緊急内視鏡検査では，食道静脈瘤が，全体の11\%を しめていた。たとえ, 静脈瘤のあることがわかってい ても, その出血が, 本当飞静脈瘤からのものなのか, ま た，そろとすれば食道内からのものか胃からのものか， ということを知り緊急処置の方法をきめるためにも, 緊急内視鏡検植の必要性を強調するものである。

\section{参考文献}

1）杉江三部 - 他 : 食道静脈瘤の内視鏡所見判 定 基 準, 肝臟, $17: 566,1976$.

2 ）遠藤光夫 - 他：食道静脈瘤の内視鏡的検討, 近藤 台五郎他編, 今日の消化器病の診断と治療, p. 149, 医学図書出版, 1972.

3 ) 三戸康部・他：食道静脈瘤飞対する内視鏡診断, 臨床外科, $29: 173,1974$.

4 ) 平島毅 - 他 : 食道静脈瘤に対する経腹的食道粘膜 離断術の手術適応, 臨床外科, $31: 635,1976$.

5 ）熊谷義也・他：食道静脈瘤の内視鏡分類とその臨 床的意義, 胃と腸, $11: 741,1976$.

(別刷請求 : $\mathbf{\mp} 162$ 東京都新宿区市谷河田町10

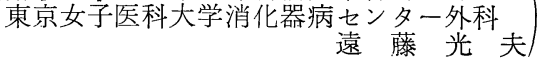

（投稿受付 1978 年10月 6 日） 